\title{
Identification customer satisfaction and brand loyalty between customers of Bank Refah Kargaran in Tehran city - Iran
}

\author{
${ }^{1}$ Zahra Poorkarimi kokand, ${ }^{2}$ Dr Zeinolabedin amini sabegh \\ 1 Student of executive management, Saveh Science and Research branch, Islamic Azad University, Saveh, Iran. \\ 2 Department of Public management, Islamic Azad University, saveh branch, Saveh, Iran
}

\begin{abstract}
Intense competition in the market and the importance of retaining customers for organizations encourage them to move towards the establishment and preservation of long-term relationships with their customers. According to researchers, relationship marketing is the most appropriate solution to achieve this goal. In this article, we discussed the effect of the foundations of relationship marketing including commitment, confidence, and communication on customer satisfaction and loyalty, the importance of these variables in the view of customers and the success of banks in the creation of these variables. This article is a descriptive study carried out by sampling method. The target population for this research consisted of 384 Refah-e-Karegaran bank customers in Tehran. We used questionnaires to collect data which were analyzed by the Pearson correlation and multiple regression methods in SPSS 16 software. The research results show that the variables of confidence - engagement - communication, which are the foundations of relationship marketing, have a significant effect on customer satisfaction. Another result obtained in this research is that the variable of customer satisfaction is an important factor to have loyal customers.
\end{abstract}

Keywords: Relationship marketing - Confidence - Customer satisfaction-Commitment - Communication.

\section{Introduction}

Today, companies with a better performance in different industries try to retain their customers and to foster their loyalty, because most markets are at the stage of maturity, and the competition is growing to which the cost of attracting new customers must be added. Keeping customers and fostering their loyalty are vital to the continuation of business. To this end, banking sector is no exception. Relationship marketing, which is a new approach in research, demonstrated its inevitable success. Organizations in Iran are required to know gradually the need to pay attention to the requirements of their clients. They need more than ever to move towards the loyalty of their customers and the satisfaction of their needs. With the emergence of private banks and public banks and the intensity of competition between them, the relationship marketing can be considered as a solution to this problem in banks. To achieve this, banks have always tried to present plans and solutions to establish and preserve long-term relationships with their customers and to foster their loyalty.

\section{Problem Statement}

Customer satisfaction and meeting their needs play a vital role in the survival of banks. But today, customer satisfaction is no longer sufficient, and the companies, organizations and banks should not be limited to it. They should ensure that their customers are as satisfied as loyal. Marketing evolution is in a stage where marketers simply do not care about the satisfaction of their customers; further marketing today has as purpose to manage demands in leading customers to maturity and loyalty towards organizations. Researches have shown that the cost of services to a loyal customer is much less than the cost to attract a new customer and to provide it with services. By identifying the needs of customers, relationship marketing can foster customer royalty and reduce organizational costs. The idea of relationship marketing is formally developed for the first time by Berry in the field of rendering services. This marketing was regarded initially as a strategy to attract, maintain and improve relationships with customers. Katler defines relationship marketing as a solution to create, maintain and improve close relationships with customers and other stakeholders. Also, Gronrouz introduced this type of marketing as a process to identify, create, maintain, enhance and, where necessary, terminate relationships with customers and other stakeholders in a bilateral interest, so that all groups realize their objectives . This study seeks to determine how relationship marketing can influence satisfaction and customer loyalty to banks, a marketing measured here in three dimensions namely: the confidence of customers towards bank employees, commitment of banks which provide customers with services and communication skills.

\section{Research hypotheses}

In this study, two main hypotheses and three secondary hypotheses were presented as follows: 
First main hypothesis: There is a relationship between relationship marketing and customer satisfaction.

\section{Secondary hypotheses:}

- There is a relationship between confidence and customer satisfaction.

- There is a relationship between commitment and customer satisfaction.

- There is a relationship between communication and customer satisfaction.

Second main hypothesis: There is a relationship between customer satisfaction and brand loyalty.

\section{Research hypotheses testing}

To test research hypotheses, we decided to use parametric tests (for example, regression and Pearson correlation methods), so the prerequisite was to verify the normal distribution of data regarding research variables. To do this, Kolmogorov-Smirnov test was used. The results are shown in the table below:

Checking the normal distribution function of research variables according to Kolmogorov-Smirnov test

\begin{tabular}{|c|c|c|c|c|c|c|}
\hline Description & Confidence & $\begin{array}{c}\text { Customer } \\
\text { satisfaction }\end{array}$ & Commitment & Communication & $\begin{array}{c}\text { Brand } \\
\text { loyalty }\end{array}$ & $\begin{array}{c}\text { Relationship } \\
\text { marketing }\end{array}$ \\
\hline $\mathrm{Z}$ & 1.155 & 1.341 & 1.128 & 1.160 & 0.771 & 1.108 \\
\hline $\begin{array}{c}\text { Significance } \\
\text { level }\end{array}$ & 0.142 & 0.055 & 0.157 & 0.136 & 0.592 & 0.251 \\
\hline
\end{tabular}

Significance level, presenting all variables, was calculated greater than 0.0.5. We can therefore say that the distribution of data on these variables has no significant relationship with the normal distribution.

To verify the relationship between variables and customer satisfaction, the bivariate regression was used.

First main hypothesis: There is a relationship between confidence and customer satisfaction.

Correlation coefficient between these two variables is 0.854 . Then according to significance level, it should be said that there is a very significant relationship between customer confidence and satisfaction. Given the calculated coefficient which was R $2=0.730$, it should be said that about $73 \%$ of changes in customer satisfaction can be interpreted by their confidence.

General determinants of regression analysis of the relationship between confidence and customer satisfaction

\begin{tabular}{|c|c|c|c|c|c|}
\hline Regression model & $\begin{array}{c}\text { Correlation } \\
\text { coefficient }\end{array}$ & $\begin{array}{c}\text { Determination } \\
\text { coefficient } \\
\text { R2 }\end{array}$ & $\begin{array}{c}\text { Adjusted } \\
\text { correlation } \\
\text { coefficient } \\
\text { R }\end{array}$ & F ignificance level \\
\hline 1 & 0.854 & 0.730 & 0.729 & 784.295 & 0.000 \\
\hline
\end{tabular}

Regression coefficient of relationship between customer confidence and satisfaction

\begin{tabular}{|c|c|c|c|c|c|}
\hline Regression model & $\begin{array}{c}\text { Regression } \\
\text { coefficient }\end{array}$ & Standard deviation & Standard beta & $\mathrm{t}$ & Significance level \\
\hline Fixed coefficient & -2.925 & 1.079 & 0.854 & -2.712 & 0.007 \\
\hline $\begin{array}{c}\text { Customer } \\
\text { confidence }\end{array}$ & 1.023 & 0.037 & & 28.005 & 0.000 \\
\hline
\end{tabular}

The results of regression ( $\mathrm{Sig}=0.000$ and $\beta=0.854$ ) above indicate that the confidence of customers has a significant effect on their satisfaction, and with one unit of growth in their confidence, 0.854 growth units should be expected for their satisfaction. (Thus, there is no reason to reject this hypothesis).

\section{Secondary hypotheses: There is a relationship between commitment and customer satisfaction.}

Correlation coefficient between these two variables is 0.854 . Then according to significance level, it should be said that there is a very significant relationship between customer commitment and satisfaction. Given the calculated coefficient which was R2 $=0.729$, it should be said that about $73 \%$ of changes in customer satisfaction can be interpreted by their commitment.

General determinants of regression analysis of the relationship between commitment and customer satisfaction

\begin{tabular}{|c|c|c|c|c|c|}
\hline Regression model & $\begin{array}{c}\text { Correlation } \\
\text { coefficient }\end{array}$ & $\begin{array}{c}\text { Determination } \\
\text { coefficient } \\
\text { R2 }\end{array}$ & $\begin{array}{c}\text { Adjusted } \\
\text { correlation } \\
\text { coefficient } \\
\text { R }\end{array}$ & F ignificance level & F \\
\hline 1 & 0.854 & 0.729 & 0.728 & 780.316 & 0.000 \\
\hline
\end{tabular}


Regression coefficient of relationship between customer confidence and satisfaction

\begin{tabular}{|c|c|c|c|c|c|}
\hline Regression model & $\begin{array}{c}\text { Regression } \\
\text { coefficient }\end{array}$ & Standard deviation & Standard beta & $\mathrm{t}$ & Significance level \\
\hline Fixed coefficient & 3.795 & 0.846 & 0.854 & 4.485 & 0.333 \\
\hline $\begin{array}{c}\text { Customer } \\
\text { commitment }\end{array}$ & 0.916 & 0.033 & & 27.934 & 0.000 \\
\hline
\end{tabular}

The results of regression ( $\mathrm{Sig}=0.000$ and $B=0.854$ ) above indicate that the commitment of customers has a significant effect on their satisfaction, and with one unit of growth in their commitment, 0.854 growth units should be expected for their satisfaction. (Thus, there is no reason to reject this hypothesis).

\section{Third secondary hypothesis: There is a relationship between customer satisfaction and communication.}

Correlation coefficient between these two variables is 0.804 . Then according to significance level, it should be said that there is a very significant relationship between customer satisfaction and communication. Given the calculated coefficient which was $\mathrm{R} 2=0.646$, it should be said that about $65 \%$ of changes in customer satisfaction can be interpreted by their communication.

General determinants of regression analysis of the relationship between customer satisfaction and communication

\begin{tabular}{|c|c|c|c|c|c|}
\hline $\begin{array}{c}\text { Regression } \\
\text { model }\end{array}$ & $\begin{array}{c}\text { Correlation } \\
\text { coefficient }\end{array}$ & $\begin{array}{c}\text { Determination } \\
\text { coefficient } \\
\mathrm{R} 2\end{array}$ & $\begin{array}{c}\text { Adjusted } \\
\text { correlation } \\
\text { coefficient } \\
\mathrm{R}\end{array}$ & $\mathrm{F}$ & $\begin{array}{c}\text { Significance } \\
\text { level }\end{array}$ \\
\hline 1 & 0.804 & 0.646 & 0.645 & 529.754 & 0.000 \\
\hline
\end{tabular}

Regression coefficient of relationship between communication and brand loyalty

\begin{tabular}{|c|c|c|c|c|c|}
\hline Regression model & $\begin{array}{c}\text { Regression } \\
\text { coefficient }\end{array}$ & Standard deviation & Standard beta & Significance level \\
\hline Fixed coefficient & -1.306 & 1.615 & 0.776 & -0.809 & 0.419 \\
\hline Communication & 1.563 & 0.075 & & 20.967 & 0.000 \\
\hline
\end{tabular}

The results of regression ( $\mathrm{Sig}=0.000$ and $\beta=0.776$ ) above indicate that communication with customers has a significant effect on their brand loyalty, and with one unit of growth in their communication, 0.776 growth units should be expected for their brand loyalty. (Thus, there is no reason to reject this hypothesis).

\section{First main hypothesis: There is relationship between relationship marketing and customer satisfaction}

Correlation coefficient between these two variables is 0.898 . Then according to significance level, it should be said that there is a very significant relationship between customer satisfaction and relationship marketing. Given the calculated coefficient which was R $2=0.806$, it should be said that about $80 \%$ of changes in customer satisfaction can be interpreted by their relationship marketing.

General determinants of regression analysis of the relationship between customer satisfaction and relationship marketing

\begin{tabular}{|c|c|c|c|c|c|}
\hline Regression model & $\begin{array}{c}\text { Correlation } \\
\text { coefficient }\end{array}$ & $\begin{array}{c}\text { Determination } \\
\text { coefficient } \\
\text { R2 }\end{array}$ & $\begin{array}{c}\text { Adjusted } \\
\text { correlation } \\
\text { coefficient } \\
\mathrm{R}\end{array}$ & F & Significance level \\
\hline 1 & 0.898 & 0.806 & 0.805 & 1202.615 & 0.000 \\
\hline
\end{tabular}

Regression coefficient of relationship between customer satisfaction and relationship marketing

\begin{tabular}{|c|c|c|c|c|c|}
\hline Regression model & $\begin{array}{c}\text { Regression } \\
\text { coefficient }\end{array}$ & Standard deviation & Standard beta & Significance level \\
\hline Fixed coefficient & -2.881 & 0.871 & 0.898 & -3.307 & 0.000 \\
\hline Communication & 0.394 & 0.011 & & 34.679 & 0.000 \\
\hline
\end{tabular}

The results of regression ( $\mathrm{Sig}=0.000$ and $\beta=0.898)$ above indicate that relationship marketing has a significant effect on their customer satisfaction, and with one unit of growth in the relationship marketing, 0.776 growth units should be expected for customer satisfaction. (Thus, there is no reason to reject this hypothesis).

Second main hypothesis: There is a relationship between customer satisfaction and brand loyalty. 
General determinants of regression analysis of the relationship between customer satisfaction and brand loyalty

\begin{tabular}{|c|c|c|c|c|c|}
\hline Regression model & $\begin{array}{c}\text { Correlation } \\
\text { coefficient }\end{array}$ & $\begin{array}{c}\text { Determination } \\
\text { coefficient } \\
\mathrm{R}^{2}\end{array}$ & $\begin{array}{c}\text { Adjusted } \\
\text { correlation } \\
\text { coefficient } \\
\mathrm{R}\end{array}$ & F & Significance level \\
\hline 1 & 0.900 & 0.809 & 0.809 & 123.958 & 0.000 \\
\hline
\end{tabular}

Regression coefficient of relationship between customer satisfaction and brand loyalty

\begin{tabular}{|c|c|c|c|c|c|}
\hline Regression model & $\begin{array}{c}\text { Regression } \\
\text { coefficient }\end{array}$ & $\begin{array}{c}\text { Standard } \\
\text { deviation }\end{array}$ & Standard beta & Significance level \\
\hline Fixed coefficient & -0.546 & 0.950 & 0.900 & -0.575 & 0.566 \\
\hline Communication & 1.211 & 0.034 & & 35.099 & 0.000 \\
\hline
\end{tabular}

The results of regression ( $\mathrm{Sig}=0.000$ and $\beta=0.900$ ) above indicate that customer satisfaction has a significant effect on their brand loyalty, and with one unit of growth in customer satisfaction, 0.900 growth units should be expected for brand loyalty. (Thus, there is no reason to reject this hypothesis).

\section{Conclusion:}

Based on the analyses performed, it should be noted that relationship marketing is an effective element in customer satisfaction. In addition, the high degree of satisfaction leads to loyalty. Therefore, banks which are trying to retain their customers need to pay more attention to their needs, their proposals and grievances regarding banking. It is the voice of customers that bank policies should be based on. Respect for customers, proper interaction with them, their survey, establishment of an appropriate and bilateral relationship with them, investigating their grievances in a timely manner, identifying their satisfaction, providing them with quality and fast services, adaptation of banking policies with their needs ... and validation of provided services can all help banks keep their clients. And this is possible only when the banks agree that attention to the needs and requirements of customers is the secret which secures the survival of banks.

\section{References:}

[1]. Brown Michael E. Trevino Linda K, Ethical Leadership: A review and future directors, leadership Quarterly 17 (2006) 595-616.

[2]. Garcia-Morales Victor J. Matias - Reche Fernando,2008), Hurtado- Torres Naria, Influence of transformational Leadership on organizational innovation and performance depending on the level of organizational learning in the pharmaceutical sector, Journal of Organizational Change Management. Vol. 21, Issue: 2, PP: 188-212, 2008.

[3]. Liden Robert G. Wayne Sandy J. Zhao Hao,(2002) Henderson Darrid, Servant Leadership: Development of a multidimensional measure and multi-level assessment, Leadership Quarterly 19,161-177.

[4]. Sekaran. Uma (2002), Research Methods for Business: A Skill Building Approach. 4th edition. New York: Joun Wiley \& Sons .

[5]. ToorShamas-ur-Rehman, Ofori George, Leadership for future construction industry: Agenda for authentic Leadership. International Journal of Project Management, 4 June 2007. (Article in Press 